\title{
Lise Son Sınıf Öğrencilerinin Üstbiliş Becerileri ile Akademik Erteleme Davranışları Arasındaki İlişki
}

\author{
Mesut Fatih DEMIR \\ Kırşehir Ahi Evran Üniversitesi, Çiçekdağı Meslek Yüksekokulu, Çocuk Bakımı ve Gençlik Hizmetleri Bölümü, Kırşehir \\ m.demir@ahievran.edu.tr \\ ORCID ID: https://orcid.org/0000-0001-7114-9775 \\ Nuri BALOĞLU \\ Kırşehir Ahi Evran Üniversitesi, Eğitim Fakültesi, Eğitim Bilimleri Bölümü, Kırşehir \\ nbaloglu@ahievran.edu.tr \\ ORCID ID: https://orcid.org/0000-0002-7982-2116
}

\begin{tabular}{lrr} 
Araştırma Makalesi & DOI: $10.31592 /$ aeusbed.640030 \\
\hline Geliş Tarihi:30.10.2019 & Revize Tarihi: 28.01 .2020 & Kabul Tarihi: 28.01.2020
\end{tabular}

\section{Atıf Bilgisi}

Demir, M. F. ve Baloğlu, N. (2020). Lise son sınıf öğrencilerinin üstbiliş becerileri ile akademik erteleme davranışları arasındaki ilişki. Ahi Evran Üniversitesi Sosyal Bilimler Enstitüsü Dergisi, 6(1), 242-259.

\section{ÖZ}

$\mathrm{Bu}$ araştırmada lise son sınıf öğrencilerinin üstbiliş becerileri ve akademik erteleme davranışları arasındaki ilişkiler öğrencilere ait bazı değişkenler açısından incelenmiştir. Çalışma ilişkisel tarama modeline uygun olarak tasarlanmıştır. Araştırmanın evreni 2017-2018 eğitim öğretim yılı içerisinde İç Anadolu Bölgesindeki bir il merkezinde bulunan ortaöğretim kurumlarının (liselerin) son sınıf öğrencilerinden oluşmaktadır. Araştırma örneklemi kolayda örnekleme yöntemi yardımı ile belirlenmiş ve araştırmaya gönüllü olarak katılmıș 492 lise son sınıf öğrencisinden oluşmaktadır. Araștırma verileri araștırmacı tarafından hazırlanan bir kişisel bilgi formu, "Üstbiliş Becerileri Ölçeği” ve "Akademik Erteleme Ölçeği” ile toplanmıştır. Veriler SPSS 22.00 paket programı kullanılarak çözümlenmiştir. Çözümlemede frekans ve yüzde, madde ortalamaları, Kolmogrov-Smirnov Testi, Kruskal Wallis-H testi, Mann-Whitney U Testi ve Spearman Brown Sıra Farkları Korelasyon Analizi tekniklerinden yararlanılmıştır. Elde edilen bulgular lise son sınıf öğrencilerinin üstbiliş becerileri ile akademik erteleme davranışı puanlarının genel olarak orta düzeyde olduğunu göstermektedir. Üstbiliş beceri puanları öğrencilerin cinsiyet ve anne-baba eğitim düzeyi değișkenine göre değișmezken, ailenin sosyo-ekonomik düzeyi ve devam edilen lise türüne göre anlamlı farklılıklar arz etmektedir. Akademik erteleme puanları ailenin sosyo-ekonomik düzeyi, annenin eğitim düzeyi ve babanın eğitim düzeyi değişkenine göre değişmezken; öğrencilerin cinsiyet ve devam ettikleri lise türü değişkenine göre anlamlı farklılıklar arz etmektedir. Öğrencilerin üstbiliş puanları ile akademik erteleme davranışı puanları arasında .18 düzeyinde pozitif yönlü düşük bir ilişki olduğu tespit edilmiştir. Araştırma sonuçları ilgili literatür temelinde tartışılmış ve bulgulara dayalı bazı öneriler sunulmuştur.

Anahtar Kelimeler: Akademik erteleme, lise son sınıfı, üstbiliş.

\section{Relationship Between Metacognition Skills and Academic Procrastination Behaviors of the High School Students}

\begin{abstract}
In this study, the relationships between metacognition skills and academic procrastination behaviors of senior high school students were examined in terms of some variables of students. The study was designed in accordance with the relational survey model. The population of the research consists of the last year students of secondary schools (high schools) in a city center in the Central Anatolia Region in the 2017-2018 academic years. The sample of the study consisted of 492 high school senior students who volunteered to participate in the study. The research data were collected with "Metacognition Skills Scale" and "Academic Procrastination Scale. The data were analyzed by using SPSS 22.00 package program. Frequency and percentage, item averages, Kolmogrov-Smirnov Test, Kruskal Wallis-H test, Mann-Whitney U Test and Spearman Brown Rank Differential Correlation Analysis techniques were used in the analysis. Findings indicate that metacognition skills and academic procrastination scores of high school senior students are generally at medium level. While metacognition skill scores do not change according to the gender and parental education level of the students, they show significant differences according to the socio-economic level of the family and the type of high school in which they are attending. Academic procrastination scores did not change according to the socio-economic level of the family, the education level of the mother and the education level of the father; there are significant differences according to gender and high school type of students. It was found that there was a low positive correlation between the metacognition scores of the students and the academic procrastination scores .18. The results of the research were discussed on the basis of the relevant literature and some recommendations based on the findings were presented.
\end{abstract}

Keywords: Academic procrastination, senior high school, metacognition. 


\section{Giriş}

Günlük yaşantımızın seyri içerisinde maruz kaldığımız hızlı değişimler, insanların zamana karşı bir yarış halinde olmasını gerekli kılmaktadır (Aydın ve Koçak, 2016). Bu durum karşısında yapmamız gereken görev ve sorumlulukların yerine getirilmesinde zamanı etkili kullanabilmenin önemi oldukça artmıştır. Zaman kavramının önemi arttıkça aynı orantıda erteleme davranışında da artış yaşanmıştır.

Üstbellek kavramından türeyen üstbiliş kavramını ilk kullanan araştırmacı Flavell'e göre üstbiliş (1979) öğrenmenin farkında olup yapılandırarak belleğe alma, bellekteki bilgileri tarayarak gerekli olanları bulup ortaya koyma ve bellekte yer alan bilgileri izleyip farkında olabilmedir.

Birey için yalnızca eğitim alanında değil yaşamın her alanında büyük bir önem arz eden üstbiliş konusu ile ilgili pek çok araştırma, sınıflandırma ve modelleme yapılmıştır (Efklids, 2006; Flavell, 1979; Hertzog ve Robinson, 2005; Paris ve Parecki, 1993; Pintrich, Wolters ve Baxter, 2000). Yapılan araştırmalarda zamanla daha net bir model oluşmuş (Efklids, 2006; Özsoy, 2007) ve modern çalışmalarda üstbiliş Üstbilişsel Kontrol ve Üstbilişsel Bilgi olmak üzere iki ana başlıkta toplanmıştır (Özsoy, 2007). Üstbilişsel kontrol; tahmin, planlama, izleme ve değerlendirme kavramlarını içermektedir. Üstbilişsel bilgi ise yordama bilgisi, bildirimsel bilgi, duruma bağlı bilgi ve bunları etkileyen birey değişkenleri, görev değişkenleri ve strateji değişkenlerini içermektedir.

Schraw ve Moshman'a göre (1995) üstbilişsel kontrol, bireyin düşünme ve öğrenme kontrolünü sağlamaya yardımcı olan etkinliklerdir. Bu iki yazara göre üstbilişsel kontrol çalışmaları üstbilişsel beceriler olarak karşımıza dört alt boyutu çıkmaktadır. Bunlar; tahmin, planlama, izleme ve değerlendirmedir. Tahmin; bireyin yapmak zorunda olduğu işin ne kadar zaman alacağı, süreçleri, sonuçları, süreç sırasındaki zorluklar ve beklentileri tahmin ederek düzenleyebilmesidir. Planlama; görevin gerçekleştirilmesinde kullanılacak olan stratejilerin seçimini ve performansın etkilendiği kaynaklardan ayrılmasını kapsamaktadır. İzleme; bireyin problemi çözme süreci veya görevi hakkında kendi bilişsel durumuna ilişkin olarak yine kendine verdiği bilgidir. Değerlendirme; görev performansına ilişkin olarak bireyin kendi öğrenme ürünlerine ve öğrenmeyi düzenleyici süreçlere değer biçmesi olarak tanımlanmaktadır (Saraç, 2010).

Üstbilişsel bilgi, bir durumda bireyin kendi zihinsel kaynaklarında sahip olduğu bilgi ve tutumlardır. Üstbilişsel bilgi, bireyin kendi bilişsel yetenekleri, bilişsel stratejileri ve nerde ne yapacağını bilme gibi bilgilere sahip olması (Doğan, 2009) veya bilişsel süreçlerin nasıl gerçekleştiğine ilişkin olarak ne bildiğimizdir (Flavell, 1979; Pintrich, 2002). Üstbilişsel bilgi 'yordama bilgisi, bildirimsel bilgi ve duruma dayalı bilgi' olmak üzere üç boyuta ayrılmıştır. Yordama bilgisi bir işin nasıl başarıyla sonuçlandırılacağını, nasıl yapılacağını bilmektir (Doğan, 2009). Bildirimsel bilgi bireyin görev ile ilgili genel bilgisidir (Memiş ve Arıcan, 2013). Duruma bağlı bilgi bireyin bilişsel etkinlikleri ne zaman ve ne için uygulanacağını bilmesidir (Schraw ve Moshman, 1995).

Üstbilişsel bilgiyi daha iyi anlayabilmek için bazı değişkenler hakkında da bilgi sahibi olmak gerekmektedir. Özsoy (2007, ss. 16-17) bu değişkenleri üç başlık altında toplamıştır. Buna göre:

“(1) Birey Değişkenleri: Üstbiliş becerisine sahip bir bireyden beklenen en önemli özellikler grubu olup, bireyin bilişsel süreçlerinin niteliğinden haberdar olmasını içermektedir.

(2) Görev Değişkenleri: Bireyin karşılaşmış olduğu bilginin doğasını ve karşıllaşmış olduğu problem veya görev hakkında sahip oldukları bilgileri içermektedir.

(3) Strateji Değişkenleri: Bireyin karşılaşmış olduğu bir problemi çözmede veya yerine getirmesi gereken bir görevi sonlandırmada kullanabileceği strateji bilgileridir.”

Erteleme davranışı, daha çok modern çağın bir hastalığı olarak görülse de bu davranışın insanlık hayatının başlamasıyla ortaya çıtığını söyleyebiliriz. Kavram olarak ertelemenin karşımıza daha belirgin olarak çıkması modern çağ olarak da adlandırılan sanayi devrimi sonrasına denk 
gelmektedir. İstek ve beklentilerin artmasının doğal bir sonucu olarak ertelemelerde de artış meydana gelmiş̧ir. Günümüz istek ve şartlarının doğal bir sonucu olan erteleme son dönemlerde oldukça dikkat çeken bir kavram olarak araştırmalara da konu olmaya başlamıştır.

Literatür bulgularına dayalı olarak erteleme, bireyin yapması gereken görev, iş veya herhangi bir eylemi mantıksızca ve gereksizce başka bir zamana ertelemesi ya da hiç yapmaması olarak tanımlanabilir (Ackerman ve Gross, 2005; Burka ve Yuen, 1983; Eerde-Van, 2003; Knaus, 1998; Milgram ve Tenne, 2000). Senecal, Julien ve Guay (2003) akademik ertelemeyi, akademik görevlere başlamayı veya tamamlamayı geciktirme konusundaki irrasyonel eğilim olarak dile getirmektedirler. $\mathrm{Bu}$ bakış açısında dikkat edilmesi gereken önemli bir nokta mantıksız ve gerekçesiz ifadeleridir. Yani, eğer birey yapacağı işleri gerekçeli ve mantıklı sebeplerden ötürü bilerek geciktiriyor ise bu durum erteleme davranışı ile ilişkilendirilmemelidir. Bununla birlikte mantıksız ve gerekçesiz erteleme hemen hemen tüm bireylerde gözüken evrensel bir davranış sorunudur. Her yaş ve cinsiyetteki bireyde de görülebilmektedir.

Erteleme kavramı; kişilik özelliği olarak erteleme (Solomon ve Rothblum, 1984) ve durumsal erteleme (Lay, 1986) olmak üzere 2 ana gruba ayrılmıştır. Kişilik özelliği olarak erteleme kavramı literatürde kompülsif, sürekli, kronik ve işlevsel olmayan erteleme olarak da isimlendirilmektedir. $\mathrm{Bu}$ kavram çeşitli görevlerin ertelenmesini, başlangıcının geciktirilmesi veya yapılamaması gibi davranışların alışkanlık haline getirilmesini ifade etmektedir. Durumsal erteleme ise bireyin belirli bir alanda görevlerini geciktirmesi veya hiç yapmaması durumunu alışkanlık haline getirmeyi ifade etmektedir. Durumsal erteleme kavramıyla ilgili olarak en fazla araştırmalara konu olan ve yaygın olan türü akademik ertelemedir.

Akademik erteleme kavramı genel anlamda akademik alandaki görevlerin gerekçesiz olarak ileriye atılması, aksatılması veya yapılmaması olarak görülebilir. Akademik erteleme; bireyin yapmas1 gereken akademik görevlerini zamanında yapmayıp, yüksek düzeyde stres yaşayana kadar da bu görevi geciktirmesidir (Senecal, Koestner ve Vallerand, 1995). Solomon ve Rothblum (1984) akademik ertelemeyi sınava hazırlanma, dönem ödevi hazırlama, okulla ilgili işler ve katılım görevleri gibi temel akademik görevlerin geciktirilmesi olarak tanımlamışlardır. Schouwenberg ve Lay (1995) 'in yaptıkları bir tanımda akademik erteleme bir ödevin teslim tarihinden hemen önce yapılması veya geciktirilmesi, kitapların kütüphaneye vaktinden sonra verilmesi ve sınava hazırlık ile geçmesi gereken zamanın başka işlerle harcanması olarak ifade edilmektedir. Bu açıklamalar akademik erteleme davranışının oldukça geniş bir alanının bulunduğu göstermektedir.

$\mathrm{Bu}$ çalışmada ise lise son sınıf öğrencilerinin üstbiliş becerileri ile akademik erteleme davranışları arasındaki ilişkiler konu olarak ele alınmaktadır.

\section{Yöntem}

$\mathrm{Bu}$ çalışma; lise son sınıf öğrencilerinin üstbiliş becerilerini, akademik erteleme davranışları arasındaki ilişkileri incelemeyi içeren ilişkisel tarama modelinde tasarlanmıştır. İliş̧kisel araştırmalar genellikle değişkenler arasındaki bağlantıları incelemektedir. Tarama araştırmaları ise bir grubun belirli özelliklerini ortaya koymaya çalışmaktadır. (Büyüköztürk, Kılıç-Çakmak, Akgün, Karadeniz ve Demirel, 2012). Karasar'a göre (2007) tarama modelleri herhangi bir durumu değiştirmeden, olanı olduğu biçimiyle tanımlamaya çalışma çabasıdır.

\section{Evren ve Örneklem}

Araştırma evrenini, 2017-2018 eğitim öğretim y1lı içerisinde İç Anadolu Bölgesi'ndeki bir il merkezinde bulunan ortaöğretim düzeyinde (liselerde) öğrenim gören son sinıf öğrencileri oluşturmaktadır. Araştırma evreninin "İç Anadolu Bölgesi'ndeki bir il merkezi” şeklinde kodlanarak ifade edilmesinin üç sebebi bulunmaktadır. Bunlar:

(1) Veri toplama araçlarının uygulaması için alınacak izinde kolaylık sağlaması. 
(2) Çalışma grubunun görüşlerini daha rahat ifade edebilmesinin sağlanması.

(3) Araştırma sonucunda elde edilen bulguların herhangi bir etiketlemeye meydan vermemesinin sağlanmasıdır.

Araştırma evreninde (özel okullar ve özel eğitim okulları dâhil) 28 ortaöğretim (lise) kurumu bulunmaktadır. Araştırma evreninde toplam 2143 öğrenci yer almaktadır. Araştırmanın çalışma grubu evrende yer alan 5 lise türünden tesadüfi örnekleme yöntemi yardımı ile seçilmiş ve araștırmaya gönüllü olarak katılmış toplam 492 öğrenciden oluşmaktadır. 2017-218 öğretim yılı itibari ile ÖSYM'nin yayınlamış olduğu okul türleri tablosunda ortaöğretim kurumları 15 farklı türe ayrılmıştır. Bununla birlikte bu çalışmada ortaöğretim kurumlarından toplumun beklentisi ve bakış açısı ile bu kurumların öğrenci kabul puanları göz önünde bulundurularak 5 türü araştırma kapsamına alınmıştır.

Lise türlerinin 5'e indirgenmesinin temel nedeni çalışmanın daha anlaşılır olmasını sağlamak, çalışmayı daha düzenli hale getirmek ve çalışmanın daha rahat yorumlanabilmesini sağlamaktır. Öğrencilerin aile gelir düzeyleri 2018 yılındaki asgari ücret ve katları dikkate alınarak düzenlenmiştir.

Çalışma grubunda yer alan katılımcıların demografik bilgileri Tablo 1'de verilmiştir.

Tablo 1

Çalışma Grubunun Demografik Bilgilerine İlişkin Frekans ve Yüzde Dağılımları

\begin{tabular}{|c|c|c|c|c|c|c|c|c|}
\hline $\begin{array}{l}\text { Seçene } \\
\text { kler }\end{array}$ & & 1 & 2 & 3 & 4 & 5 & 6 & $\begin{array}{l}\text { Topla } \\
\text { m }\end{array}$ \\
\hline \multirow{3}{*}{$\begin{array}{l}\text { Cinsiye } \\
\mathrm{t}\end{array}$} & & Kadın & Erkek & & & & & \\
\hline & $\mathrm{N}$ & 242 & 250 & & & & & 492 \\
\hline & $\%$ & 49,2 & 50,8 & & & & & 100 \\
\hline \multirow{4}{*}{$\begin{array}{l}\text { Aile } \\
\text { Sosyo- } \\
\text { Gelir } \\
\text { Düzeyi }\end{array}$} & & 1603 Lira ve & $1603-3206$ & $3206-5616$ & 5616 Lira & & & \\
\hline & & Alt1 & Lira Arası & Lira Arası & ve Üzeri & & & \\
\hline & $\mathrm{N}$ & 143 & 177 & 136 & 36 & & & 492 \\
\hline & $\%$ & 29,1 & 36,0 & 27,6 & 7,3 & & & 100 \\
\hline \multirow{3}{*}{$\begin{array}{l}\text { Anne } \\
\text { Eğitim } \\
\text { Düzeyi }\end{array}$} & & $\begin{array}{l}\text { Okuma- } \\
\text { Yazma }\end{array}$ & İlkokul & Ortaokul & Lise & Üniversite & $\begin{array}{l}\text { Yüksek } \\
\text { Lisans }\end{array}$ & \\
\hline & $\mathrm{N}$ & Bilmiyor & 163 & 150 & 110 & 47 & 11 & 492 \\
\hline & $\%$ & $\begin{array}{r}11 \\
2,2\end{array}$ & 33,1 & 30,5 & 22,4 & 9,6 & 2,2 & 100 \\
\hline \multirow{3}{*}{$\begin{array}{l}\text { Baba } \\
\text { Eğitim } \\
\text { Düzeyi }\end{array}$} & & $\begin{array}{l}\text { Okuma- } \\
\text { Yazma }\end{array}$ & İlkokul & Ortaokul & Lise & Üniversite & $\begin{array}{c}\text { Yüksek } \\
\text { Lisans }\end{array}$ & \\
\hline & $\mathrm{N}$ & Bilmiyor & 109 & 136 & 131 & 97 & 12 & 492 \\
\hline & $\%$ & 1,4 & 22,2 & 27,6 & 26,6 & 19,7 & 2,4 & 100 \\
\hline
\end{tabular}

\section{Veri Toplama Araçları}

Araştırmada bir kişisel bilgi formu ile iki adet ölçek kullanılmıştır. Bu araçlara ait nitelikler aşağıda açıklanmıştır. 
Kişisel Bilgi Formu: Araştırmada katılımcılara ait demografik bilgiler ile araştırmanın bağımsız değişkenlerine ilişkin bilgileri toplamak amacıyla araştırmacılar tarafından geliştirilmiştir.

Üstbiliş Becerileri Ölçeği: Lise son sınıf öğrencilerinin üstbiliş becerilerini belirlemek amacıyla Altındağ (2008) tarafından geliştirilen ve Altındağ ve Senemoğlu (2013) tarafından yayımlanan "Yürütücü Biliş Becerileri Ölçeği"nin temeli "Bireyin Öğrenme Etkinliklerini Düzenlemesi Ille Ilgili Faktörler" $i$ gösteren modelden yola çıkılarak hazırlanmış, beşli likert tipi, otuz maddeli bir ölçektir. Ölçeğin geliştirildiği gruptaki en düşük madde faktör yükü 0,44 olarak bulunmuştur. Faktör analizi sonuçlarına göre ölçeğin tek boyutlu olduğu ve 30 madde ile toplam varyansın \%35,74'ünü açıkladığı tespit edilmiştir. Ölçeğin ön deneme Cronbach Alpha güvenirlik katsayısı 0,94 olarak bulunmuştur. Ölçeğin 492 lise son sınıf öğrencisi üzerinde yürütülen bu çalışma kapsamında güvenirlik analizi yeniden yapılmıştır. Cronbach's Alpha Güvenirlik Katsayısı .90 olarak tespit edilmiştir.

Akademik Erteleme Ölçeği: Üniversite öğrencilerinin akademik erteleme davranış düzeyini belirlemek amacıyla Çakıcı (2003) tarafından geliştirilmiştir. Akademik Erteleme Ölçeği, öğrencilerin öğrenim yaşantılarında yapmakla sorumlu oldukları görevleri içeren 12 olumsuz, 7 olumlu olmak üzere toplam 19 ifadeden oluşmaktadır. Ölçekte yer alan ifadelere verilen tepkiler "beni hiç yansıtmıyor", "beni çok az yansitıyor", "beni biraz yansitıyor", "beni çoğunlukla yansitıyor", "beni tamamen yansitıyor" biçiminde olmak üzere beş basamaklı likert tipinde derecelendirilmektedir. Ölçek akademik erteleme içeren bir ifadeye "beni hiç yansıtmıyor" diyenler 1, "beni tamamen yansıtıyor" diyenler 5 puan alacak biçimde tek yönlü puanlanmaktadır. Ölçekte ters madde yer almamaktadır. Ölçekten alınabilecek en yüksek puan 95, en düşük puan 19'dur. Ölçekten alınan yüksek puan, öğrencilerin akademik ertelemeci olduklarını göstermektedir. Ölçeğin Cronbach's Alpha Güvenirlik Katsayısı ölçeğin bütünü için .74 olarak tespit edilmiştir. Akademik erteleme ölçeğinin Ölçeğin 492 lise son sınıf öğrencisi üzerinde yürütülen bu çalışma kapsamındaki çalışma grubundaki Cronbach's Alpha Güvenirlik Katsayısı.74 olarak tespit edilmiştir.

\section{Verilerin Analizi}

Veriler bilgisayar ortamında SPSS 22.00 paket programı ile çözümlenmiştir. Veri toplama araçlarından elde edilen bilgilerin bilgisayar ortamına aktarılması esnasında eksik doldurulmuş 12 ölçek iptal edilmiş ve analizler 492 birim üzerinden yapılmıştır. Çözümlemede frekans ve yüzde, madde ortalamaları, çalışmanın normallik dağılımını incelemek için Kolmogrov-Smirnov Testi, aile gelir düzeyi, anne eğitim düzeyi, baba eğitim düzeyi ve okudukları lise türü ilişkisinin belirlenmesi için Kruskal Wallis-H testi, katılımcıların cinsiyet değişkenleri ilişkisinin belirlenmesi için MannWhitney U Testi ve üstbiliş ile akademik erteleme puanları arasındaki ilişkinin belirlenmesi için Spearman Brown Sıra Farkları Korelasyon Analizi tekniklerinden yararlanılmıştır.

\section{Bulgular}

\section{Lise Son Sınıf Öğrencilerinin Üstbiliş Becerileri ve Akademik Erteleme Puanlarına İlişkin Bulgular}

Lise son sınıf öğrencilerinin; üstbiliş ve akademik erteleme puan ortalamalarına ilişkin bulgular Tablo 2'de verilmiştir.

Tablo 2

Lise Son Sinı Öğrencilerinin Üstbiliş ve Akademik Erteleme Davranış Puanlarının Aritmetik Ortalama $(\overline{\mathrm{x}})$ ve Standart Sapma (SS) Değerleri

\begin{tabular}{lrrrrr} 
& $\mathrm{n}$ & Min. & Max. & $\overline{\mathrm{x}}$ & ss \\
\hline Üstbiliş & 492 & 1,00 & 5,00 & 3,27 &, 65
\end{tabular}


Tablo 2'de lise son sınıf öğrencilerinin; üstbiliş beceri puan ortalamalarının 3,27 olduğu ve bu puanlara ait standart sapma değerinin de 0,65 olduğunu görülmektedir. Öğrencilerin Akademik Erteleme puan ortalamalarının ise 3,10 ve bu puanlara ait standart sapma değerinin de 0,64 olduğu görülmektedir. Buna göre araştırmaya katılmış olan lise son sınıf öğrencileri üstbiliş becerileri ve akademik erteleme puanları teorik ortalamanın (3.00) biraz üzerindedir. Bununla birlikte, öğrencilerde üst biliş beceri puanlarının daha yüksek ve erteleme davranışlarının da daha düşük olması beklenen bir durumdur.

\section{Lise Son Sınıf Öğrencilerinin Üstbiliş Puanlarının Cinsiyet Değişkenine Göre Dağı̆lımına İliş̧kin Bulgular}

Lise son sınıf öğrencilerinin üstbiliş puanlarının cinsiyet değişkenine göre sıra ortalama (s.o.) değerleri ile bu ortalamalar arasındaki farklara ilişkin yapılan Mann-Whitney U testi sonuçları Tablo 3 'te verilmiştir.

Tablo 3

Öğrencilerin “Cinsiyet” Değişkenine Göre Üstbiliş Puan Ortalamaları ile Bu Ortalamalar Arasındaki Farklara İlişkin Mann-Whitney U Testi Sonuçları

\begin{tabular}{ccccc}
\hline & Gruplar & $\mathrm{N}$ & s.o & $\mathrm{p}$ \\
\hline & Erkek & 250 & 251,55 & \\
Üstbiliş & Kadın & 242 & 241,28 &, 423 \\
\hline
\end{tabular}

Tablo 3'te örneklem grubunda 250 erkek ve 242 kadın lise son sınıf öğrencisinin üstbiliş puanları bulunmaktadır. Öğrencilerinin üstbiliş puanlarının cinsiyet değişkenine göre anlamlı farklılık gösterip göstermediğine ilişkin yapılan Mann-Whitney-U testi sonuçları kadın ve erkek öğrencilerin üstbiliş puanları arasında anlamlı bir farklık olmadığını göstermektedir ( $>>0,05)$.

\section{Lise Son Sınıf Öğrencilerinin Akademik Erteleme Puanlarının Cinsiyet Değişkenine Göre Dağılımına İliş̧kin Bulgular}

Lise son sınıf öğrencilerinin akademik erteleme puanlarının cinsiyet değişkenine göre sıra ortalama (s.o) değerleri ile bu puanlar arasındaki farka ilişkin olarak yapılan Mann-Whitney U testi sonuçları Tablo 3 ’te verilmiştir.

Tablo 4

Öğrencilerinin "Cinsiyet” Değişkenine Göre Akademik Erteleme Puan Ortalamaları ile Bu Ortalamalar Arasındaki Farka İlişkin Mann-Whitney U Testi Sonuçları

\begin{tabular}{lrrrr}
\hline Değişkenler & Gruplar & N & s.o & p \\
\hline \multirow{2}{*}{ Akademik Erteleme } & Erkek & 250 & 267,46 & \\
& Kadın & 242 & 224,84 &, 001 \\
\hline
\end{tabular}

Lise son sınıf öğrencilerinin üstbiliş becerilerinin cinsiyet değişkenine göre gruplanması yoluyla oluşturulan gruplar arasındaki ortalama farkının anlamlı olup olmadığını tespit etmek üzere yapılan Mann-Whitney-U testinin sonuçlarına göre; öğrencilerdeki akademik erteleme davranışının cinsiyet değişkenine göre manidar bir farklılık arz ettiği görülmektedir. $(p<0.05) . B u$ duruma göre erkek öğrencilerdeki akademik erteleme davranışlarının kadın öğrencilere göre manidar olarak daha yüksek olduğu anlaşılmaktadır. 


\section{Lise Son Sınıf Öğrencilerinin Aile Gelir Düzeylerine Göre Üstbiliş Puanlarına İlişkin Bulgular}

Araştırma kapsamında yer alan lise son sınıf öğrencilerinin aile gelir düzeylerine göre üstbiliş puanlarına ilişkin bulgular Tablo 5'te verilmiştir.

\section{Tablo 5}

“Aile Gelir Düzeylerine” Göre Lise Son Sinı Öğrencilerinin Üstbiliș Puan Ortalamalarına İlişkin Kruskal Wallis-H Testi Sonuçları

\begin{tabular}{|c|c|c|c|c|c|}
\hline Değişken & Gruplar & $\mathrm{N}$ & s.o & $\mathrm{sd}$ & $\mathrm{p}$ \\
\hline \multirow{4}{*}{ Üstbiliş } & 1603 lira ve alt 1 & 143 & 210,04 & \multirow{4}{*}{3} & \multirow{4}{*}{,003 } \\
\hline & $\begin{array}{r}1603-3206 \text { lira } \\
\text { aras1 }\end{array}$ & 177 & 260,02 & & \\
\hline & $\begin{array}{r}4809-6412 \text { lira } \\
\text { aras } 1\end{array}$ & 136 & 257,35 & & \\
\hline & $\begin{array}{r}6412 \text { lira ve } \\
\text { üzeri }\end{array}$ & 36 & 283,88 & & \\
\hline
\end{tabular}

Tablo 5'te görüldüğü üzere, araştırma kapsamında yer alan öğrencilerin aile gelir düzeyleri asgari ücretin katlarına göre gruplandığında, ailesi asgari ücretin altında gelir düzeyine sahip öğrencilerin üstbiliş puan ortalamaların en düşük seviyede olduğu; buna karşılık aile gelir düzeyi asgari ücretin dört katı (6412 TL) ve üzerinde gelir düzeyine sahip öğrencilerin üst biliş puanlarının da en yüksek düzeyde olduğu görülmektedir. Bu gelir durumlarına göre gruplanmış olan öğrencilerin üstbiliş puanları arasındaki farkın manidar olup olmadığına ilişkin yapılan Kruskal Wallis testi sonucuna göre; üstbiliş becerisi bakımından aile gelir düzeyine göre gruplar arasında anlamlı farkların bulundu $(\mathrm{p}=, 003)$ sonucuna ulaşı1mıştır $(\mathrm{p}<0.05)$.

\section{Lise Son Sınıf Öğrencilerinin Aile Gelir Düzeylerine Göre Akademik Erteleme Davranışlarına İlişkin Bulgular}

Araştırma kapsamındaki lise son sınıf öğrencilerinin aile gelir düzeyleri asgari ücretin katları dikkate alınarak dört farklı grupta toplanmıştır. Öğrencilerdeki akademik erteleme davranışının bu gruplara göre farklılık oluşturup oluşturmadığını tespit etmek amacıyla yapılan Kruskal Wallis-H testi sonuçları Tablo 6'da verilmiştir.

Tablo 6

Lise Son Sını Öğrencilerinin “Aile Gelir Düzeylerine” Göre Akademik Erteleme Puan Ortalamaları Arasındaki Farklara Illişkin Kruskal Wallis-H Testi Sonuçları

\begin{tabular}{|c|c|c|c|c|c|}
\hline Değişkenler & Gruplar & $\mathrm{N}$ & s.o & sd & $\mathrm{p}$ \\
\hline & 1603 lira ve & 143 & 240,2 & & \\
\hline & alt1 & & 9 & & \\
\hline \multirow{6}{*}{$\begin{array}{l}\text { Akademık } \\
\text { Erteleme }\end{array}$} & 1603-3206 lira & 177 & 245,2 & 3 &, 556 \\
\hline & arası & & 9 & & \\
\hline & 3206-5616lira & 136 & 246,2 & & \\
\hline & aras1 & & 2 & & \\
\hline & 5616 lira ve & 36 & 278,1 & & \\
\hline & üzeri & & 9 & & \\
\hline
\end{tabular}

Tablo 6'da görüldüğü gibi araştırma örnekleminde yer alan 492 lise son sınıf öğrencisinin, akademik erteleme davranış puanlarının aile gelir düzeyine göre dört grup şeklinde ele alınmasıyla oluşturulan grup ortalamaları arasındaki farklara ilişkin olarak yapılan Kruskal Wallis testi sonucunda bu ortalamalar arasında $(\mathrm{p}>0.05)$ anlamlı bir fark olmadığı görülmektedir. 


\section{Lise Son Sınıf Öğrencilerinin Anne Eğitim Düzeylerine Göre Üstbiliş Puanları Arasındaki Farklara İlişkin Bulgular}

Lise son sınıf öğrencilerinin üst biliş puanlarının anne eğitim düzeyine göre gruplanması yoluyla elde edilen gruplar arasındaki ortalama farklarına ilişkin bulgular Tablo 7'de verilmiştir.

Tablo 7

Lise Son Sinı Öğrencilerinin “Anne Eğitim Düzeylerine” Göre Üstbiliş Puan Ortalamaları Arasındaki Farklara İlişkin Kruskal Wallis-H Testi Sonuçları

\begin{tabular}{rrrrrr}
\hline Değişken & Gruplar & N & s.o & sd & p \\
\hline \multirow{4}{*}{ Üstbiliş̧ } & Okuma-yazma & 11 & 224,86 & & \\
& bilmiyor & 163 & 243,42 & 5 &, 698 \\
& İlkokul & 150 & 249,49 & & \\
& Ortaokul & 110 & 256,45 & & \\
& Lise & 47 & 243,80 & & \\
& Üniversite & 11 & 185,00 & & \\
& Yüksek Lisans & &
\end{tabular}

Tablo 7'de görüldüğü üzere lise son sinıf öğrencilerinin anne eğitim düzeyleri 6 grupta toplanmıştır. Grup görüşleri arasındaki ortalama farklarına ilişkin yapılan Kruskal Wallis testi sonucuna göre öğrencilerinin anne eğitim düzeylerine göre grup görüşleri arasında $(\mathrm{p}>0.05)$ anlamlı bir fark olmadı $\breve{g} 1(p=, 698)$ tespit edilmiştir.

\section{Lise Son Sınıf Öğrencilerinin Anne Eğitim Düzeylerine Göre Akademik Erteleme Puanlarına İlişkin Bulgular}

Lise son sınıf öğrencilerinin akademik erteleme puanları anne eğitim düzeyi değişkenine göre 6 ayrı grup görüşü olarak ele alınmıştır. Bu grup görüşleri arasındaki ortalama farkının manidar olup olmadığına ilişkin yapılan Kruskal Wallis-H testi sonuçları Tablo 8'de verilmiştir.

Tablo 8

Lise Son Sinlf Öğrencilerinin “Anne Eğitim Düzeylerine” Göre Akademik Erteleme Puan Ortalamaları Arasındaki Farklara İlişkin Kruskal Wallis-H Testi Sonuçları

\begin{tabular}{lrrrrr}
\hline Değişkenler & Gruplar & N & s.o & sd & p \\
\hline & Okuma-yazma & 11 & 302,00 & & \\
& bilmiyor & & & & \\
Akademik Erteleme & İlkokul & 163 & 234,49 & &, 434 \\
& Ortaokul & 150 & 255,60 & 5 & \\
& Lise & 110 & 250,91 & & \\
& Üniversite & 47 & 228,46 & & \\
& Yüksek Lisans & 11 & 277,82 & & \\
& & & & & \\
\end{tabular}

Tablo 8'de görüldüğü üzere lise son sınıf öğrencilerinin akademik erteleme puanları anne eğitim düzeyine göre 6 grup halinde ele alındığında Kruskal Wallis testi sonucuna göre bu grup görüşleri arasındaki ortalama farkının $(\mathrm{p}>0.05)$ anlamlı bir fark oluşturmadığ $\quad(p=, 434)$ gözlenmektedir. 


\section{Lise Son Sınıf Öğrencilerinin Baba Eğitim Düzeylerine Göre Üstbiliş Puan Ortalamaları Arasındaki Farklara İlişkin Bulgular}

Lise son sınıf öğrencilerinin üstbiliş puanlarının Baba Eğitim Düzeyine göre gruplanması yoluyla oluşturulan gruplar arasındaki ortalama farkları üzerine yapılan Kruskal Wallis $\mathrm{H}$ testi sonuçları Tablo 9'da verilmiştir.

Tablo 9

“Baba Eğitim Düzeylerine” Göre Lise Son Sınıf Öğrencilerinin Üstbiliş Ölçeği Ortalamaları Kruskal Wallis-H Testi Sonuçları

\begin{tabular}{rrrrrr}
\hline Değişkenler & Gruplar & $\mathrm{N}$ & s.o & sd & p \\
\hline \multirow{4}{*}{ Üstbiliş } & Okuma-yazma & 7 & 223,29 & & \\
bilmiyor & & & 5 &, 626 \\
İlkokul & 109 & 235,10 & & \\
Ortaokul & 136 & 259,11 & & \\
Lise & 131 & 241,56 & & \\
& Üniversite & 97 & 255,08 & & \\
& Yüksek Lisans & 12 & 205,21 & & \\
\hline
\end{tabular}

Tablo 9'ta görüldüğü üzere, lise son sınıf öğrencilerinin üstbiliş puanlarının baba eğitim düzeyine göre gruplanması yoluyla oluşturulan gruplar arasındaki ortalama farkına uygulanan Kruskal Wallis H testi sonuçlarının ( $>>0.05)$ düzeyinde anlamlı bir fark $(p=, 626)$ oluşturmadığı görülmektedir.

\section{Lise Son Sınıf Öğrencilerinin Baba Eğitim Düzeyi Değişkenine Göre Akademik Erteleme Puanlarının Arasındaki Farklara İlişskin Bulgular}

Lise son sınıf öğrencilerinin akademik erteleme puanlarının baba eğitim düzeyine göre gruplanması yoluyla oluşturulan grup ortalamaları arasındaki farklara ilişkin Kruskal Wallis H testi sonuçları Tablo 10'da verilmiştir.

Tablo 10

Lise Son Sinıf Öğrencilerinin Akademik Erteleme Puanlarının "Baba Ĕgitim Düzeyine” Göre Gruplanması Yoluyla Oluşturulan Gruplar Arasındaki Ortalama Farklarına İliş̧kin Kruskal Wallis-H Testi Sonuçları

\begin{tabular}{lrrrrr}
\hline Değişkenler & Gruplar & N & s.o & sd & p \\
\hline & $\begin{array}{r}\text { Okuma-yazma } \\
\text { bilmiyor }\end{array}$ & 7 & 330,86 & & \\
Akademik & İlkokul & 109 & 249,11 & 5 &, 100 \\
Erteleme & Ortaokul & 136 & 265,32 & & \\
& Lise & 131 & 235,77 & & \\
& Üniversite & 97 & 221,59 & \\
& Yüksek Lisans & 12 & 278,75 & \\
\end{tabular}

Tablo 10'da görüldüğü üzere lise son sınıf öğrencilerinin akademik erteleme puanlarının baba eğitim düzeyine göre gruplanması yoluyla oluşturulan gruplar arasındaki farklara ilişkin olarak yapılan 
Kruskal Wallis $H$ testi sonuçlarının $(p>0.05)$ arasında anlamlı bir farklılık $(p=, 100)$ oluşturmadığ 1 görülmektedir.

\section{Lise Son Sınıf Öğrencilerinin Lise Türlerine Göre Üstbiliş Puanları Arasındaki Farklara İlişkin Bulgular}

Lise son sınıf ögrencilerinin üstbiliş puanlarının lise türlerine göre gruplanması yoluyla elde edilen grup ortalamaları arasındaki farklara ilişkin bulgular Tablo 11'de verilmiştir.

Tablo 11

Lise Son Sinıf Öğrencilerinin "Okul Türüne” Göre Üstbiliş Puan Ortalamaları Arasındaki Farklara İlişkin Kruskal Wallis-H Testi Sonuçları

\begin{tabular}{rrrrrr}
\hline Değişkenler & Gruplar & N & s.o & sd & p \\
\hline \multirow{4}{*}{ Üstbiliş } & Meslek ve & 169 & 207,41 & & \\
& Teknik Liseler & & & & \\
Özel Liseler & 76 & 268,96 & & \\
Anadolu & 96 & 294,41 & & \\
Liseleri & & & & \\
& İmam Hatip & 59 & 248,87 & \\
Liseleri & & 248,24 & \\
\hline
\end{tabular}

Tablo 11'de lise son sınıf öğrencilerinin üstbiliş puanlarının lise türlerine göre gruplanması yoluyla oluşturulan gruplar arasındaki ortalama farklarına uygulanan Kruskal Wallis $\mathrm{H}$ testi sonuçlarının $(\mathrm{p}<0,05)$ düzeyinde anlamlı $(, 000)$ olduğu görülmektedir. Bu bulguya göre üst biliş beceri ortalaması en yüksek lise türünün Anadolu Liseleri en düşük olanın da Mesleki ve Teknik Liseler olduğu görülmektedir.

\section{Lise Son Sınıf Öğrencilerinin Okudukları Lise Türlerine Göre Akademik Erteleme Puanları Arasındaki Farklara İlişkin Bulgular}

Lise son sınıf öğrencilerinin Akademik Erteleme puanlarının lise türlerine göre gruplanması yoluyla elde edilen ortalamalar arası farkların manidar olup olmadığına ilişkin olarak yapılan Kruskal Wallis H testi sonuçları Tablo 12'de verilmiştir.

Tablo 12

Lise Son Sinıf Öğrencilerinin "Okul Türüne” Göre Akademik Erteleme Puan Ortalamaları Arasındaki Farklara İlişkin Kruskal Wallis-H Testi Sonuçları

\begin{tabular}{lrrrrr}
\hline Değişkenler & Gruplar & N & s.o & sd & p \\
\hline & Meslek ve & 169 & 236,4 & & \\
& teknik liseler & & 3 & & \\
Akademik & Özel Liseler & 76 & 260,4 & 4 & \\
Erteleme & & & 5 & 215,5 & \\
& Anadolu & 96 & 6 & & \\
& Liseleri & & 276,0 & \\
& İmam Hatip & 59 & 6 & \\
Liseleri & & 92 & 266,8 & \\
& Sosyal Bilimler & & 1 & \\
Lisesi & &
\end{tabular}


Tablo 12'de lise son sınıf öğrencilerinin Akademik Erteleme puanlarının lise türlerine göre gruplanması yoluyla oluşturulan grup ortalamaları arasında farklara ilişkin olarak yapılan Kruskal Wallis testi sonucunun $(\mathrm{p}<0,05)$ düzeyinde anlamlı farklılıklar içerdiği $(, 032)$ görülmektedir. Buna göre akademik erteleme davranışının en yüksek düzeyde İmam Hatip Lisesi, en düşük düzeyde de Anadolu Lisesi öğrencilerde olduğu görülmektedir.

\section{Lise Son Sınıf Öğrencilerinin Üstbiliş Becerileri Toplam Puanları ve Akademik Erteleme Toplam Puanları Aralarındaki İlişskiye Yönelik Bulgular}

Lise son sınıf öğrencilerinin üstbiliş becerileri toplam puanları ve akademik erteleme toplam puanları arasındaki korelasyonel ilişkinin tespit edilmesi için yapılan Spearman Brown Sıra Farkları Korelasyon Analizi sonuçları Tablo 13’te verilmiştir.

Tablo 13

Lise Son Sinı Öğrencilerinin Üstbiliş Beceri Puanları ile Akademik Erteleme Puanları Arasındaki Spearman Brown Sira Farkları Korelasyon Analizi Sonuçları

\begin{tabular}{lrrrr}
\hline Değişken & $\mathrm{n}$ & $\mathrm{r}$ & $\mathrm{p}$ \\
\hline Üstbiliş & 492 &, $180^{* *}$ &, 000 \\
Akademik Erteleme & & & \\
\hline
\end{tabular}

Tablo 13 incelendiğinde lise son sınıf öğrencilerinin üstbiliş beceri puanları ile akademik erteleme davranış puanları arasında pozitif yönlü $\left(\mathrm{r}=, 180^{* *}\right)$ bir korelasyon olduğu görülmektedir.

\section{Sonuç, Tartıșma ve Öneriler}

Araştırma kapsamında lise son sınıf öğrencilerinin üstbiliş becerileri ile akademik erteleme davranışı puanlarının genel olarak orta düzeyde olduğu tespit edilmiştir. Üstbiliş becerisi, yani kendi bilişsel süreçlerini kontrol edebilme düzeyi lise son sınıf öğrenciler arasında orta seviyededir. $\mathrm{Bu}$ bulguya iyimser olarak yaklaşmak mümkündür. Ancak üstbiliş becerilerini kullanma düzeylerinin lise son sınıf öğrencilerinde yüksek düzeyde çıkması istenen bir durumdur. Bu durum öğrencilerin üstbiliş becerilerini kullanma düzeylerinin arttırmak için çalışmalar yapılması gerektiğini işaret etmektedir. Buna benzer şekilde öğrencilerinin akademik erteleme davranışı gösterme düzeylerinin orta seviyede çıkması da istenmeyen bir durumdur. Yine bu sonuç lise öğrencilerinde akademik erteleme davranışının daha düşük düzeye çekilmesi için bazı çalışmalar yapılmasını işaret etmektedir.

Üstbiliş beceri puanları öğrencilerin cinsiyetlerine göre değişmemektedir. Elde edilen bu sonuç Deniz, Küçük, Cansız, Akgün ve İşleyen (2014), Doğan (2009), Öztürk-Ova (2011), Özsoy ve Kuloğlu (2017), Aykut, Karasu ve Kaplan (2016) ve Sarpkaya, Arık ve Kaplan (2011) tarafindan yapılan çalışmalarla benzerlik gösterirken Nazik, Sönmez ve Güneş (2014), Adıgüzel ve Orhan (2016), Altındağ (2008), Arıcan Demir (2013), Memiş ve Arıcan (2013), Gül, Özay Köse ve SadiYılmaz (2015) tarafından yapılan çalışmalarla da farklılıklar göstermektedir. Bunun nedeni farklı çalışmalarda farklı yaş gruplarının ele alınarak incelenmesi, eğitim düzeylerinin farklı seviyede olması ve farklı kültürel çevrelerin cinsiyet kavramına farklı anlamlar yüklemiş olmaları olabilir.

Üstbiliş beceri puanları anne ve baba eğitim düzeylerine göre anlamlı bir fark oluşturmamaktadır. Bu durum Nazik, Sönmez ve Güneş (2014), Karslı (2015), Sarpkaya, Arıkan ve Kaplan (2011), Baloğlu ve Demir (2017), Gürültü (2016) ve Öztürk-Ova (2011) tarafindan yapılan çalışmalarla benzerlik göstermektedir. Fakat Demir ve Özmen Kaymak (2011) tarafından yapılan çalışmayla da bir zıtlık göstermektedir. Bu durumun nedeni olarak da bu araştırmadaki çalışma grubunu oluşturan öğrencilerin anne ve babalarının kendilerini geliştirme durumları ve ailenin gelir düzeyinin etkili olduğu söylenebilir. 
Üstbiliş beceri puanları ailenin gelir düzeylerine göre anlamlı farklılıklar arz etmektedir. $\mathrm{Bu}$ bulgu Karslı (2015), Sarpkaya, Arık ve Kaplan (2011) ve Baloğlu ve Demir (2017) tarafından yapılan çalışmalarla farklılık göstermektedir. Öğrencilerin üstbiliş beceri puanları devam edilen lise türüne göre de anlamlı farklilıklar arz etmektedir. Bu bulgu Adıgüzel ve Orhan (2016), Kacar ve Sarıçam (2015) ve Öztürk-Ova (2011) tarafından yapılan çalışmalarla zıtlık göstermektedir. Bunun nedeni olarak da katılımcıların yaşadığı bölgedeki sosyo-ekonomik düzey ve kültürel farklılıklar olabilir. Ayrıca çalışma grubunda yer alan öğrencilerin eğitim gördükleri okulların örgüt kültürü özelliklerini de dikkate almak gerekir.

Akademik erteleme puanları ailenin gelir düzeyine göre anlamlı farklılık arz etmektedir. $\mathrm{Bu}$ sonuç Kandemir (2010) ve Tanrıkulu (2013) tarafından yapılan çalışmalarla benzerlik göstermektedir. Ancak Gürültü (2016) tarafından yapılan çalışmayla da zitlık göstermektedir. Bu durum, gelir düzeyinin farklı kültürel çevrelerde farklı etki düzeyi oluşturması olabilir. Ayrıca bu çalışmaya katılan lise son sınıf öğrencilerinin aile gelir düzeylerinin sayısal olarak birbirinden oldukça farklı olmaları da bu sonuca etki etmiş olabilir.

Akademik erteleme puanları annenin eğitim düzeyi ve babanın eğitim düzeyi değişkenine göre anlamlı farklılık bulunmamaktadır. Yine bu sonuç Kandemir (2010), Arslan (2013) ile benzerlik gösterirken Tanrıkulu (2013) tarafindan yapılan çalışma ile de zıtlık göstermektedir. Bu bulgunun baba eğitim düzeyi ile benzer sonuçlar ortaya koyması ise araştırmanın bir tutarlılık göstergesi olarak değerlendirilebilir.

Akademik erteleme puanları öğrencilerin cinsiyetlerine göre anlamlı farklılık arz etmektedir. Elde edilen bu sonuç Çakıcı (2003), Kandemir (2010), Sarıoğlu (2011), Arslan (2013), Gürültü (2016), Çetin (2016) ile benzerlik göstermektedir. Ancak yine bu sonuç Yiğit ve Dilmaç (2011) tarafindan yapılan çalışma ile zıtlık göstermektedir. Akademik erteleme davranışının erkek öğrencilerde daha yüksek çıkması ise kültürün bu araştırma sonuçlarına doğrudan yansıması olarak görülebilir.

Akademik erteleme puanları öğrencilerin devam ettikleri lise türü değişkenine göre anlamlı farklılıklar arz etmektedir. Elde edilen bu sonuç Sarığlu (2011), Ekinci (2011), Gürültü (2016), Yiğit ve Dilmaç (2011) ile benzerlik göstermektedir. Ancak elde edilen bu sonuç Çetin (2016) ile zitlık göstermektedir. Elde edilen sonuçlardaki farklılıkların nedeni okulların örgüt kültürleri ile toplumun bu okullara atfettiği genel bakış açısı olabilir. Ayrıca anlamlı farkın oluşmasında okulların sahip olduğu başarı düzeylerini de göz ardı etmemek gerekir.

Öğrencilerin üstbiliş puanları ile akademik erteleme davranışı puanları arasında .18 düzeyinde pozitif yönlü bir ilişki tespit edilmiştir. Bu bulgu, araştırmanın beklenen bir bulgusu değildir. Yani, öğrencilerdeki üstbiliş becerisi arttıkça erteleme davranışının azalması daha beklenen bir sonuç olacaktı. Bu durumdan hareketle, akademik erteleme davranışının gerçekte algılandığı kadar olumsuz ve kötü bir şey olmadığı sonucunu çıkartılabilir. Çünkü üstbiliş becerisi yüksek olan bireyler kendi zihinsel süreçlerini kontrol edebilen, yaptıklarının ve sürecin farkında olan bir kişilerdir. Yani, öğrenciler üstbiliş becerisi arttıkça erteleme davranışı sergilemede kendilerince mantıklı sebepler üretmekte olabilirler. Bir başka ifade üstbiliş becerisi güçlü olan öğrencilerin akademik erteleme sonucunda karşılaşacakları durumlara kendilerini hazırladıkları düşünülebilir.

Araştırma kapsamında elde edilen bu bulgular 1şığında başka araştırmacılar şu öneriler üzerinde durulabilir. Bu çalışma nicel bir araştırmadır. Aynı örneklem grubunda nitel çalışmalar yapılmalıdır. Bu çalışmada akademik erteleme davranışı genel olarak olumsuz bir durum olarak ele alınmıştır. Yeni çalışmalarda akademik erteleme davranışının olumlu etkileri olup olmadığı konusu üzerine odaklanmalar olabilir. Bu araştırmada örneklem grubu olarak sadece lise son sinıf öğrencileri seçilmiştir. Yapılacak yeni çalışmalarda farklı örneklem grupları belirlenerek aynı çalışmalar bu guruplar üzerinde tekrarlanabilir. Son olarak bu araştırma İç Anadolu Bölgesinde yer alan bir il merkezindeki resmi okullarda uygulanmıştır. Yapılacak yeni çalışmalar farklı il, bölge ve özel öğretim kurumları öğrencilerinin üzerinde yürütülebilir. 
Açıklamalar: $\mathrm{Bu}$ çalışma, birinci yazar tarafindan Kırşehir Ahi Evran Üniversitesi Sosyal Bilimler Enstitüsünde tamamlanan "Lise Son Sınıf Öğrencilerinin Üstbiliş Becerileri ve Akademik Erteleme Davranışları Arasındaki İlişkinin İncelenmesi” başlıklı yüksek lisans tezinden üretilmiştir.

\section{Kaynaklar}

Ackerman, D. S. and Gross, B. L. (2005). My instructor made me do it: Task characteristics of procrastination. Journal Of Marketing Education, 27(1), 5-13.

Adıgüzel, A. ve Orhan, A. (2016). Öğrencilerin üstbiliş beceri düzeyleri ile İngilizce dersine ilişkin akademik başarıları arasındaki ilişki. Ihlara Eğitim Araştırmaları Dergisi, 2(1), 5-14.

Altındağ, M. (2008). Öğrencilerin yürütücü biliş becerileri. (Yüksek Lisans Tezi). Hacettepe Üniversitesi, Sosyal Bilimler Enstitüsü, Ankara.

Altındağ M. ve N. Senemoğlu (2013) Yürütücü biliş becerileri ölçeği. Hacettepe Üniversitesi Eğitim Fakültesi Dergisi, 28(1), 15-26.

Arıcan Demir, H. (2013). Beşinci sınıf öğrencilerinin matematiksel üstbiliş düzeylerinin cinsiyet ve başarı değişkenleri açısından incelenmesi. (Yüksek Lisans Tezi). Bülent Ecevit Üniversitesi, Sosyal Bilimler Enstitüsü, Zonguldak.

Arslan, A. (2013). Lise öğrencilerinin akademik erteleme davranışlarının karar verme stilleri ile ilişkisi. (Yüksek Lisans Tezi). Gaziantep Üniversitesi, Eğitim Bilimleri Üniversitesi, Gaziantep.

Aydın, S. A. ve Koçak, S. (2016). Üniversite öğrencilerinin zaman yönetimi becerileri ile akademik erteleme düzeylerinin incelenmesi. Uşak Üniversitesi Eğitim Araştırmaları Dergisi, 2(3), 1738 .

Aykut, Ç., Karasu, N. ve Kaplan, G. (2016). Özel eğitim öğretmen adaylarının üstbiliş farkındalıklarının tespiti. Ankara Üniversitesi Eğitim Bilimleri Fakültesi Özel Eğitim Dergisi, 17(3), 231-245.

Baloğlu, N. ve Demir, M. F. (2017). Sekizinci sınıf öğrencilerinin aile ilişkileri ve üstbiliş becerileri arasındaki ilişkiler. International Journal Of Eurasia Social Sciences, 30(8), 1891-1905.

Burka, J. B. and Yuen, L.M. (1983). Procrastination: Why you do it, what to do about it. New York: Addison-Wessley.

Büyüköztürk, Ş., Kılıç-Çakmak, E., Akgün, Ö. E., Karadeniz, Ş. ve Demirel, F. (2012). Bilimsel araştırma yöntemleri. Ankara: Pegem Akademi.

Çakıcı, D. C. (2003). Lise ve üniversite ögrrencilerinde genel erteleme ve akademik erteleme davranışının incelenmesi. (Yüksek Lisans Tezi). Ankara Üniversitesi, Eğitim Bilimleri Enstitüsü, Ankara.

Çetin, N. (2016). Lise öğrencilerinin akademik erteleme davranışlarının incelenmesi. Yayınlanmamış (Yüksek Lisans Tezi). Anadolu Üniversitesi, Eğitim Bilimleri Enstitüsü, Eskişehir.

Demir, Ö. ve Kaymak-Özmen, S. (2011). Üniversite öğrencilerinin üstbiliş düzeylerinin çeşitli değişkenler açısından incelenmesi. Ç. Ü. Sosyal Bilimler Enstitüsü Dergisi, 20(3), 145-160.

Deniz, D., Küçük, B., Cansız, Ş., Akgün, L., ve İşleyen, T. (2014). Ortaöğretim matematik öğretmeni adaylarının üstbiliş farkındalıklarının bazı değişkenler açısından incelenmesi. Kastamonu 
Eğitim Dergisi, 22(1), 305-320.

Doğan, E. (2009). Meslek liselerinde çalışan öğretmenlerin üstbiliş becerileri ile sosyal uyumları arasındaki iliş̧ki (İstanbul Anadolu Yakası örneği). (Yüksek Lisans Tezi). Yeditepe Üniversitesi, Sosyal Bilimler Enstitüsü, İstanbul.

Eerde Van, W. (2003). Procrastination at work and time management training. The Journal Of Psychology, 137(5), 421-434.

Efklides, A. (2006). Metacognition And Affect: What can metacognitive experences tell us about the learning process? Educational Research Review, 1(1), 3-14.

Ekinci, E. (2011). Ortaöğretim ögrencilerinin akademik özyeterlik düzeyleri ve akademik erteleme davranışlarının öğrenilmiş çaresizlik düzeylerini yordama gücü. (Yüksek Lisans Tezi). Gaziosmanpaşa Üniversitesi, Sosyal Bilimler Enstitüsü, Tokat.

Flavell, J. H. (1976). Metacognitive aspects of problem solving. İçinden Resnick, L. (Ed.), The nature of intelligence (ss. 231-236). New Jersey: Lawrence Erlbaum Associates.

Flavell, J. H. (1979). Metacognition and cognitive monitoring: A new area of cognitive developmental inquiry. American Psychologist, 34(10), 906-911.

Gül, Ş., Özay-Köse, E. ve Sadi-Yılmaz, S. (2015). Biyoloji öğretmeni adaylarının üstbiliş farkındalıklarının farklı değişkenler açısından incelenmesi. Hasan Ali Yücel Eğitim Fakültesi Dergisi, 12(23), 83-91.

Gürültü, E. (2016). Lise öğrencilerinin sosyal medya bağımlılıkları ve akademik erteleme davranışları arasındaki ilişkinin incelenmesi. (Yüksek Lisans Tezi). Marmara Üniversitesi, Eğitim Bilimleri Enstitüsü, İstanbul.

Hertzog, C. and Robinson, A. E. (2005). Metacognition and intelligence. İçinden Wilhelm, O. ve Engle, R. W. (Eds.), Handbook of understanding and measuring intelligence (ss. 101-123). London: Sage.

Kacar, M. ve Sarıçam, H. (2015). Sınıf öğretmen adaylarının üstbiliş farkındalıkları ile matematik kaygı düzeyleri üzerine bir çalışma. Trakya Üniversitesi Eğitim Fakültesi Dergisi, 5(2), 137152.

Kandemir, M. (2010). Akademik erteleme davranışını açıklayıcı bir model. (Doktora Tezi). Gazi Üniversitesi, Eğitim Bilimleri Enstitüsü, Ankara.

Karasar, N. (2007). Bilimsel araştırma yöntemi. Ankara: Nobel Yayınları.

Karslı, T. A. (2015). İlköğretim dönemindeki ergenlerde üst-biliş işlevleri ile karar verme ve denetim odağı arasındaki ilişkinin incelenmesi. Elektronik Sosyal Bilimler Dergisi, 14(55), 16-31.

Knaus, W. J. (1998). Do it now! Break the procrastination habit. (2. Bask1). New York: John Wiley\&Sons, Inc.

Lay, C. H. (1986). At last, my research article on procrastination. Journal Of Research In Personality, 20(4), 474-495.

Memiş, A. ve Arıcan, H. (2013). Beşinci sınıf öğrencilerinin matematiksel üstbiliş düzeylerinin cinsiyet ve başarı değiş̧enleri açısından incelenmesi. Karaelmas Journal of EducationalSciences, 1(2013), 76-93. 
Milgram, N. N. and Tenne, R. (2000). Personality correlates of decisional and task svoidant procrastination. European Journal Of Personality, 14(2), 141-156.

Nazik, F., Sönmez, M. ve Güneş, G. (2014). Hemşirelik öğrencilerinin üstbiliş düzeylerinin çeşitli değişkenler açısından incelenmesi. Anadolu Hemşirelik ve Sağlık Bilimleri Dergisi, 14(55), 16-31.

Oran, S. (2016). Anadolu lisesi ögrencilerinde akademik erteleme davranışlarının incelenmesi. Yüksek Lisans Tezi, Çă̆ Üniversitesi, Sosyal Bilimler Üniversitesi, Mersin.

Özsoy, F. ve Kuloğlu, M. M. (2017). Major depresif bozukluk ve panik bozukluk hastalarında üstbiliş işlevlerinin değerlendirilmesi. Journal Of Contemporary Medicine, 7(1), 42-49.

Özsoy, G. (2007). Illköğretim beşinci sinıfta üstbilişs stratejileri öğretiminin problem çözme başarısına etkisi. (Doktora Tezi). Gazi Üniversitesi, Eğitim Bilimleri Enstitüsü, Ankara.

Öztürk Ova, N. (2011). Güzel sanatlar lisesi ögrencileri ile fen lisesi ögrrencilerinin eleştirel düşünme ve üstbilis eğilimlerinin karşılaştırılması. (Yüksek Lisans Tezi). Yeditepe Üniversitesi, Sosyal Bilimler Üniversitesi, İstanbul.

Paris, S. and Parecki, A. (1993). Metacognitive aspects of adult literacy. Philadelphia, PA: National Center On Adult Literacy.

Pintrich, P. R. (2002). The role of metacognitive knowledge in learning, teaching and assessing. Theory Into Practice, 41(4), 219-225.

Pintrich, P. R., Wolters, C. A. and Baxter, G. P. (2000). Assessing metacognition and self-regulated learning. İçinde Schraw, G. ve Impara, J. C. (Ed.), Issues in the measurement of metacognition (43-97). Lincoln, NE: The University of Nebraska Press.

Saraç, S. (2010). Illköğretim beşinci sınıf ögrencilerinin üstbiliş düzeyleri, genel zeka ve okuduğunu anlama düzeyleri arasindaki ilişkinin incelenmesi. (Doktora Tezi). Marmara Üniversitesi, Eğitim Bilimleri Enstitüsü, İstanbul.

Sarpkaya, G., Arık, G. ve Kaplan, H. A. (2011). İlköğretim matematik öğretmen adaylarının üstbiliş stratejilerini kullanma farkındalıkları ile matematiğe karşı tutumları arasındaki ilişki. Sosyal Bilimler Araştırmaları Dergisi, 6(2), 107-122.

Sarıoğlu, F. A. (2011). Öğretmen adaylarının akademik erteleme eğilimi ile mükemmeliyetçilik düzeyleri arasındaki iliş̧kinin incelenmesi. (Yüksek Lisans Tezi). İstanbul Üniversitesi, Eğitim Bilimleri Enstitüsü, İstanbul.

Senecal, C., Julien, E. and Guay, F. (2003). Role conflict and academic procrastination: A selfdetermination perspective. Europen Journal Of Social Psychology, 33(1), 135-145.

Senecal, C., Koestner, R. and Vallerand, R. J. (1995). Self-regulation and academic procrastination. Journal Of Social Psychology, 135(5), 607-619.

Schouwenburg, H. C. and Lay, C. H. (1995). Trait procrastination and the big-five factors of personality. Personality And Individual Differences, 18(4), 481-490.

Schraw, G. and Moshman (1995). Metacognitive theories. Educational Psychology Review, 4(4), 351371. 
Solomon, L. J. and Rothblum, E. D. (1984). Academic procrastination: Frequency and cognitivebehavioral correlates. Journal Of Counseling Psychology, 31(4), 503-509.

Tanrıkulu, M. (2013). Ergenlerin akademik erteleme davranışlarıyla benlik saygılarının incelenmesi. (Yüksek Lisans Tezi). Dokuz Eylül Üniversitesi, Eğitim Bilimleri Enstitüsü, İzmir.

Yiğit, R. ve Dilmaç B. (2011). Ortaöğretimde öğrencilerinin sahip oldukları insani değerler ile akademik erteleme davranışlarının bazı değişkenler açısından incelenmesi. Dumlupınar Üniversitesi Sosyal Bilimler Dergisi, (31), 159-178. 


\section{Extended Abstract}

\section{Introduction}

The rapid changes we are exposed to in the course of our daily lives require people to be in a race against time. In the face of this situation, the importance of using time effectively has increased considerably in the fulfillment of the duties and responsibilities we have to do. As the importance of time concept increased, procrastination behavior increased at the same rate. Flavell is the first researcher who used the concept of metacognition.

The concept of metacognition is explained by Flavell (1979) as a mental process that individuals do and need in this process being aware of learning, structuring, memorizing and revealing. Many researches, classifications and modeling have been done about the metacognition subject which is of great importance not only in education but also in all areas of life (Efklids, 2006; Flavell, 1979; Hertzog and Robinson, 2005; Paris and Parecki, 1993; Pintrich, Wolters) and Baxter, 2000).

Although postponement behavior is seen as a disease of the modern age, it can be said that this behavior emerged with the beginning of human life. Based on the findings of the literature, procrastination can be seen as an unreasonable and unnecessary postponement of the task, work or any action that the individual should do or not to do at any other time. Academic procrastination; what the individual has to delay his/her academic tasks until he/she experiences high levels of stress (Senecal, Koestner and Vallerand, 1995).

In this study, the relationships between metacognition skills and academic procrastination behaviors of senior high school students were examined in terms of some variables of students.

\section{Method}

\section{Research Model}

The study was designed in accordance with the relational survey model. Relational studies often examine the connections between variables. Survey research tries to reveal the specific characteristics of a group.

\section{Study Group}

The population of the research consists of the last year students of secondary schools (high schools) in a city center in the Central Anatolia Region in the 2017-2018 academic years. The sample of the study consisted of 492 high school senior students who volunteered to participate in the study. The participants of the study were students selected from 5 different high school types in the universe by random sampling method.

\section{Instruments}

The research data were collected with "Metacognition Skills Scale" and "Academic Procrastination Scale. Metacognition Skills Scale was developed by Altındağ (2008) to determine the metacognition skills of high school senior students and was published by Altındağ and Senemoğlu (2013) as "Executive Cognition Skills Scale. Cronbach's Alpha Reliability Coefficient was determined as. 90. Academic Procrastination Scale was developed by Çakıcı (2003) to determine the academic procrastination behavior level of university students. The academic procrastination scale was determined as Cronbach's Alpha Reliability Coefficient.74 in the study group of 492 high school senior students. 


\section{Data Analysis}

The data were analyzed by using SPSS 22.00 package program. Frequency and percentage, item averages, Kolmogrov-Smirnov Test, Kruskal Wallis-H test, Mann-Whitney U Test and Spearman Brown Correlation Analysis techniques were used in the analysis.

\section{Findings}

Findings indicate that metacognition skills and academic procrastination scores of high school senior students are generally at medium level.

While metacognition skill scores do not change according to the gender and parental education level of the students, they show significant differences according to the socio-economic level of the family and the type of high school in which they are attending. Academic procrastination scores did not change according to the socio-economic level of the family, the education level of the mother and the education level of the father; there are significant differences according to gender and high school type of students. It was found that there was a low positive correlation between the metacognition scores of the students and the academic procrastination scores .18.

\section{Results, Conclusion and Suggestions}

Metacognition skills of high school students, that is the ability to control their cognitive processes are moderate level. This situation suggests that studies should be conducted to increase the level of students' use of metacognitive skills. Likewish, the level of academic procrastination behaviors of the students are moderate level too. Again, this result points out that some studies are carried out to reduce academic procrastination behavior to a lower level in high school students.

Metacognitive skill scores do not change according to the gender of the students. Metacognitive skill scores do not make a significant difference according to the education level of parents. But, metacognitive skill scores of students show significant differences according to family income levels. The reason for this may be discussible from different ways.

Academic procrastination scores differ significantly according to family income level. This may be because the income level creates a different level of influence in different cultural environments. There was no significant difference between academic procrastination scores according to mother's education level and father's education level. The fact that this finding shows similar results with father's education level can be considered as a consistency indicator of the study.

Academic procrastination scores differ significantly according to the gender of the students. The fact that academic procrastination behavior is higher in male students can be seen as a direct reflection of culture on these research results. Academic procrastination scores show significant differences according to the high school type variable too. This may be due to the organizational culture of schools and the general perspective attributed to society by these schools. In addition, the achievement levels of schools should not be ignored in making a significant difference.

A positive correlation (.18) was found between students' metacognition scores and academic procrastination scores. This finding is not an expected finding of the study. In other words, the higher the metacognition skills of the students, the less the procrastination behavior would be expected. From this point of view, it can be concluded that academic procrastination behavior is not as bad and negative as it is perceived.

In this study, academic procrastination behavior was generally considered as a negative situation. In other studies may focus on whether academic procrastination has positive effects. 